\title{
DIREITO FUNDAMENTAL DA PROTEÇÃO EM FACE DA AUTOMAÇÃO COMO MESCANISMO DE PROTEÇÃO AO EMPREGO
}

\section{FUNDAMENTAL LAW OF PROTECTION AGAINST AUTOMATION AS A JOB PROTECTION MASSANISM}

\section{DEBORA CRISTINA DE CASTRO DA ROCHA}

Mestre em Direito Empresarial e Cidadania, Professora e Pesquisadora - Centro Universitário Curitiba - UNICURITIBA. Curitiba - PR. e-mail: debora.dcr.adv@gmail.com

GUSTAVO DE SILVA Acadêmico do curso de Direito - Faculdade da Indústria. São José dos Pinhais - PR. E-mail: gustavo.dcr.adv@gmail.com.

\section{RESUMO}

Esta pesquisa planeja arquitetar um esboço analítico e crítico, a partir de uma revisão bibliográfica detalhada sobre $o$ assunto, retratando o direito fundamental da proteção em face da automação, previsto no inciso XXVII, do art. $7^{\circ}$, da Constituição Federal. O direito fundamental da proteção em face da automação encontra alicerçado no rol de direitos e garantias sociais contidos no texto constitucional, quer seja por meio de direitos de aspecto individual, quer seja pela efetivação de direitos coletivos. Há muito tempo já é reconhecida a necessidade de elaborar planos de proteção da classe trabalhadora dos impulsos da automação excessiva e, diga-se, abusiva. A proteção do emprego face à automação merece uma atenção especial, seja para o trabalho manual, seja para o trabalho intelectual. Aquele já vem sofrendo há bastante tempo com o avanço da tecnologia, uma vez que robôs vêm tomando espaço de 
Personalidade Acadêmica Homenageada:

Augustus B. Cochran III (Agnes Scott College)

milhões de trabalhadores em linhas de produção, o que por sua vez, demanda atenção especial voltada à inteligência artificial. Isto posto, verifica-se a necessidade de aplicação de forma direta e imediata do direito fundamental em questão, sobretudo, nas relações de emprego, onde a igualdade entre as parte é algo muito distante. Assim sendo, busca-se com escopo no princípio da dignidade da pessoa humana, tutelar de forma efetiva a disponibilização de empregos e trabalhos dignos. Diante disso, em uma primeira análise, o trabalho se pautará na busca do conceito de automação e na sua confluência com as políticas de trabalho modernas. Na sequência o aspecto constitucional do direito fundamental da proteção em face da automação, a dimensão subjetiva e objetiva do referido direito fundamental. Não obstante, revela-se imperioso tratar de toda essa ordem de situações que atingem a órbita de direitos inerentes à ordem constitucional, justamente em observância a unidade da constituição e a proteção do trabalhador que vem sido preterido gradativamente frente à evolução da sociedade e a cada vez mais crescente necessidade de desenvolvimento que não raro acaba se confrontando, ou culminando com a deflagração de princípios dentro do nosso ordenamento jurídico. A elaboração da presente pesquisa está amparada na doutrina e na legislação, objetivando o encontro de respostas voltadas à satisfação dos anseios sociais e dos direitos fundamentais em evidência, não havendo, até o presente momento resultados a serem apresentados, uma vez que o trabalho ainda está sendo desenvolvido.

PALAVRAS-CHAVE: Constituição Federal; Direitos Fundamentais; Proteção; Automação.

\section{REFERÊNCIAS}

BRASIL. Constituição da República Federativa do Brasil de 1988. Disponível em: < http://www.planalto.gov.br/ccivil 03/constituicao/constituicao.htm > Acesso em: 04 jun. 2019.

PORTELA, Irene. MARTINS, Gustavo Afonso. SILVA, Marina Zagonel Xavier da. A Quarta Revolução Industrial: A Perspectiva Constitucional Brasileira na Construção 
Personalidade Acadêmica Homenageada:

Augustus B. Cochran III (Agnes Scott College)

do Admirável Mundo Novo. In: Revista Jurídica - UNICURITIBA, vol.04, n.27, Curitiba, 2018. pp. $1 \quad$ - $\quad 4$. Disponível em: < http://revista.unicuritiba.edu.br/index.php/percurso/article/viewFile/3154/371371686 > Acesso em: 04 jun. 2019.

FILHO. Wagson Lindolfo José. A eficácia do direito fundamental da proteção em face da automação previsto no inciso XXVII, do art. $7^{\circ}$, da Constituição Federal de 1988. Revista Jus Navigandi, ISSN 1518-4862, Teresina, ano 21, n. 4820, 11 set. 2016. Disponível em: < https://www.google.com/amp/s/jus.com.br/amp/artigos/35702/1 > Acesso em: 04 jun. 2019. 